Developments in British Politics 5 
Developments titles available from Macmillan

Patrick Dunleavy, Andrew Gamble, Ian Holliday and Gillian Peele (eds)

DEVELOPMENTS IN BRITISH POLITICS 5

Peter A. Hall, Jack Hayward and Howard Machin (eds)

DEVELOPMENTS IN FRENCH POLITICS (REVISED EDITION)

Gillian Peele, Christopher Bailey, Bruce Cain and B. Guy Peters (eds)

DEVELOPMENTS IN AMERICAN POLITICS 2

Martin Rhodes, Paul Heywood and Vincent Wright (eds) DEVELOPMENTS IN WEST EUROPEAN POLITICS

Gordon Smith, William E. Paterson and Stephen Padgett (eds)

DEVELOPMENTS IN GERMAN POLITICS 2

Stephen White, Judy Batt and Paul G. Lewis (eds) DEVELOPMENTS IN EAST EUROPEAN POLITICS

Stephen White, Alex Pravda and Zvi Gitelman (eds) DEVELOPMENTS IN RUSSIAN POLITICS 4

If you have any comments or suggestions regarding this list or other Developments titles, please write to Steven Kennedy, Publishing Director, Macmillan Press Ltd, Houndmills, Basingstoke RG21 6XS, UK. 


\title{
Developments in British Politics 5
}

\author{
Edited by \\ Patrick Dunleavy \\ Andrew Gamble \\ Ian Holliday \\ Gillian Peele
}

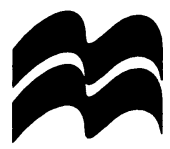


Editorial matter and selection (in order) (C) Patrick Dunleavy, Andrew Gamble, Ian Holliday and Gillian Peele 1997

Individual chapters (C) Patrick Dunleavy, John Peterson, David Sanders, Pippa Norris, Gillian Peele, Mark Evans, Philip Norton, Christopher Hood and Oliver James, Martin Loughlin and Colin Scott, Ian Holliday, Arthur Aughey, Peter John, Gavin Kelly, Catherine Jones Finer, John Benyon and Adam Edwards, Wyn Grant, Andrew Gamble 1997

All rights reserved. No reproduction, copy or transmission of this publication may be made without written permission.

No paragraph of this publication may be reproduced, copied or transmitted save with written permission or in accordance with the provisions of the Copyright, Designs and Patents Act 1988, or under the terms of any licence permitting limited copying issued by the Copyright Licensing Agency, 90 Tottenham Court Road, London W1P 9HE.

Any person who does any unauthorised act in relation to this publication may be liable to criminal prosecution and civil claims for damages.

The authors have asserted their rights to be identified as the authors of this work in accordance with the Copyright, Designs and Patents Act 1988.

First published 1997 by

MAGMILLAN PRESS LTD

Houndmills, Basingstoke, Hampshire RG21 6XS

and London

Companies and representatives

throughout the world

ISBN 978-0-333-67776-6

ISBN 978-1-349-25862-8 (eBook)

DOI 10.1007/978-1-349-25862-8

A catalogue record for this book is available from the British Library.

This book is printed on paper suitable for recycling and made from fully managed and sustained forest sources.

$\begin{array}{rrrrrrrrrr}10 & 9 & 8 & 7 & 6 & 5 & 4 & 3 & 2 & 1 \\ 06 & 05 & 04 & 03 & 02 & 01 & 00 & 99 & 98 & 97\end{array}$

Copy-edited and typeset by Povey-Edmondson

Tavistock and Rochdale, England

Published in the United States of America 1997 by

ST. MARTIN'S PRESS, ING.,

Scholarly and Reference Division

175 Fifth Avenue, New York, N.Y. 10010

ISBN 978-0-312-21010-6 


\section{Contents}

List of Contributors $\quad$ ix

Preface xii

1 Introduction: 'New Times' in British Politics

Patrick Dunleavy 1

Electoral Change and Stability 2

The Conservatives' Crisis 5

Labour Ascendant and the Centre Ground 11

New Directions in British Governance 16

$\begin{array}{ll}\text { Conclusion } & 18\end{array}$

2 Britain, Europe and the World Fohn Peterson 20

The Theoretical and International Context 21

Britain in the European Union 24

The Special Relationship $\quad 32$

The Legacy of Empire 35

Britain as an International Actor 38

$\begin{array}{ll}\text { Conclusions } & 40\end{array}$

\section{Part I: Political Behaviour}

3 Voting and the Electorate David Sanders 45

The Survey Data Perspective 46

The Aggregate Model Approach $\quad 62$

$\begin{array}{ll}\text { Conclusions } & 71\end{array}$

4 Political Communications Pippa Norris $\quad 75$

The Decline of the Pre-Modern Campaign 76

The Evolution of the Modern Campaign $\quad 80$

The Development of the Post-Modern Campaign? 87

Conclusions $\quad 88$ 
5 Political Parties Gillian Peele $\quad 89$

'New Labour' $\quad 91$

The Conservative Party 98

The Liberal Democrats 108

$\begin{array}{ll}\text { Conclusion } & 109\end{array}$

6 Political Participation Mark Evans 110

Political Participation in the UK: A Snapshot 110

Unconventional Political Participation in the UK 114

New Forms of Political Opportunity Structure 118

Explaining Changes in Political Participation 121

New Labour, New Politics? 123

\section{Part II: Political Institutions}

7 The Constitution Patrick Dunleavy 129

The Centralization of Power 133

The Devolution of Power $\quad 136$

The Declining Legitimacy of Government 140

Rebuilding Faith in Government $\quad 144$

The Unresponsive Voting System 147

The Future of Electoral Reform $\quad 150$

Conclusions 154

8 Parliamentary Oversight Philip Norton 155

The Role of Parliament 155

Marginalization? 158

Assertiveness? 160

Scrutiny by the European Parliament 172

$\begin{array}{ll}\text { Conclusion } & 176\end{array}$

9 The Central Executive Christopher Hood and Oliver James $\quad 177$

Recent Changes 177

Four Fundamental Control Mechanisms in Central

Governance 185

Assessing Public Service Change 192

Conclusion $\quad 202$ 
10 The Regulatory State Martin Loughlin and Colin Scott

Privatization and Regulation

Deregulation and Self-Regulation 210

Euro-Regulation $\quad 211$

Regulating the Public Sector 212

Conclusion $\quad 218$

11 Territorial Politics Ian Holliday 220

Territorial Politics in the UK 221

Territorial Politics and the 1997 General Election 223

Territorial Politics in the Conservative Years 225

Implementing Labour's Programme 229

Territorial Politics and the British Party System 230

Managing Territorial Political Change 236

The Future 238

12 Northern Ireland Arthur Aughey 241

The Downing Street Declaration 241

Reaction to the Ceasefires 242

The Framework Document and Decommissioning 244

Elections and Talks 246

The Talks 248

Conclusion 252

13 Local Governance Peter Fohn 253

The Restructuring of Local Politics 253

Central-Local Relations in the 1990s 257

Towards Community Governance? 266

Centralized Local Administration and Local

Government Decline? $\quad 270$

The Future $\quad 274$

\section{Part III: Public Policy}

14 Economic Policy Gavin Kelly 279

After the ERM: Rebuilding the Institutions of

Macroeconomic Policy

Evidence: Macroeconomic Policy and Trends 
viii

Policy Debates 286

Conclusion: New Debates 301

15 Social Policy Catherine Fones Finer 304

The Stakeholder Idea $\quad 305$

'Stakeholder' Social Policies 308

Conclusion 324

16 Grime and Public Order Fohn Benyon and Adam Edwards $\quad 326$

The Politicization of Crime and Public Order 327

Law and Order Under the Conservatives 328

Labour's Law-and-Order Strategy 335

Problems and Prospects 338

17 BSE and the Politics of Food Wyn Grant 342

BSE: The Disease and a Chronology 343

The Politics of Expertise 348

BSE and Devolution $\quad 350$

Britain's Relations with the European Union 351

Conclusions 353

18 Conclusion: Politics 2000 Andrew Gamble 355

The End of the Nation-State 359

The End of Ideology 361

The End of Tradition 364

The End of the Public Realm 366

The End of Government 368

The End of Security $\quad 371$

New Beginnings $\quad 373$

Further Reading 377

Bibliography $\quad 384$

$\begin{array}{ll}\text { Index } & 408\end{array}$ 


\section{List of Contributors}

Arthur Aughey is Senior Lecturer in Politics at the University of Ulster at Jordanstown. Recent publications include Northern Ireland Politics (co-edited) and three chapters in Philip Norton (ed.), The Conservative Party.

John Benyon is Professor of Political Studies and Director of the Scarman Centre for the Study of Public Order, University of Leicester. Research interests include collective violence, social protest and political stability; the politics of law and order; and crime and policing in the European union. Books include The Roots of Urban Unrest and Police Co-operation in Europe.

Patrick Dunleavy is Professor of Government at the London School of Economics and Political Science. Recent works include Prime Minister, Cabinet and Core Executive (co-edited), Democracy, Bureaucracy and Public Choice and numerous journal articles on public choice, urban politics and electoral systems.

Adam Edwards is a Research Officer at the Scarman Centre for the Study of Public Order, University of Leicester. Research interests include public policy change, learning and transfer; local governance; crime prevention; and the politics of law and order. Mark Evans is Lecturer in Politics at the University of York. Recent publications include Charter 88: A Successful Challenge to the British Political Tradition? and journal articles on British public policy and state theory.

Andrew Gamble is Professor of Politics at the University of Sheffield. He is the author of Hayek: The Iron Cage of Liberty and co-editor of Regionalism and World Order and Stakeholder Capitalism. Wyn Grant is Professor of Politics at the University of Warwick. His most recent books are The Common Agricultural Policy and Autos, Smog and Pollution Control.

Christopher Hood is Professor of Public Administration and Public Policy in the Department of Government, London School of Economics and Political Science. Recent articles related to the UK central executive include 'Deprivileging the UK Civil Service in the 1980s: Dream or Reality?' (in Jon Pierre (ed.) Bureaucracy in the Modern State) and 'Bureaucratic Regulation and New Public 
Management in the UK: Mirror-Image Developments?' (coauthored) (Journal of Law and Society, 1996).

Ian Holliday is Senior Lecturer in Government at the University of Manchester. Recent publications include The British Cabinet System (co-authored) and journal articles on British politics and policy. He co-edits the journal Party Politics.

Oliver James is Research Officer in the Department of Government, London School of Economics, and Research Associate of the Institute for Public Policy Research. Recent publications related to the UK central executive include 'Explaining the Next Steps Reform in the Department of Social Security' (Political Studies, 1995) and 'Reinventing the Treasury' (co-authored) (Public Administration, 1997).

Peter John is Lecturer in Politics at the University of Southampton. Recent publications include Analysing Public Policy and articles on public administration in the EU.

Catherine Jones Finer is Reader in Comparative Social Policy at the University of Birmingham. Recent publications include Promoting Prosperity: The Hong Kong Way of Social Policy (edited) and New Perspectives on the Welfare State in Europe. She edits the journal of Social Policy and Administration.

Gavin Kelly is Research Officer on the Corporate Governance Project at the Political Economy Research Centre, University of Sheffield. Recent publications include Stakeholder Capitalism (coedited) and articles on British economic policy.

Martin Loughlin is Professor of Law at the University of Manchester. Recent publications include Public Law and Political Theory and Legality and Locality: The Role of Law in Central-Local Government Relations.

Pippa Norris is Associate Director (Research) of the Joan Shorenstein Center on the Press, Politics and Public Policy at the Kennedy School of Government, Harvard University. Recent publications include Electoral Change since 1945 and Passages to Power: Legislative Recruitment in Advanced Democracies.

Philip Norton is Professor of Government and Director of the Centre for Legislative Studies, University of Hull. Recent publications include Does Parliament Matter? and The Conservative Party (edited).

Gillian Peele is Fellow and Tutor in Politics at Lady Margaret Hall, Oxford. Recent publications include Governing the $U K$ and 
Developments in American Politics (co-edited). She is currently working on a study of John Major and the contemporary Conservative Party.

John Peterson is Jean Monnet Senior Lecturer at the Department of Politics, University of Glasgow. Recent publications include Europe and America: The Prospects for Partnership and Decision-Making in the European Union (co-authored).

David Sanders is Professor of Government at the University of Essex. Recent articles include 'Economic Performance, Management Competence and the Outcome of the Next General Election' (Political Studies, 1996) and 'New Labour, New Machiavelli: A Cynic's Guide to Economic Policy' (Political Quarterly, 1996). Colin Scott is Lecturer in Law at the London School of Economics and Political Science. Recent publications include International Regulatory Competition and Coordination (co-edited) and articles on British public administration. 


\section{Preface}

For this fifth Developments in British Politics volume the editorial teams remains unchanged from Developments 4 , but as ever our list of authors is entirely new.

The task we set contributors this time was to analyse the challenges facing Britain's first Labour government for nearly two decades in the context both of the Conservative legacy and of the main theories and models developed by political scientists to explain British politics. All chapters are thus focused squarely on the late 1990s, and on the emerging political agenda of the twenty-first century.

Our Introduction (Chapter 1) examines the key contemporary approaches to understanding British politics, and our Chapter 2 explains Britain's place both in Europe and in the wider global order. The book then divides into three main parts. Part I analyzes constituent elements of British political behaviour. Part II investigates the key institutions of the British state. Part III examines central aspects of British public policy. Our final chapter (Chapter 18) considers the political agenda Britain will face in the twenty-first century. This structure is somewhat different from that employed in previous editions, chiefly because it integrates shorter issues chapters into the main parts of the book. New topics covered in this edition include political participation, crime and public order, and a special case study of BSE and the politics of food.

The timing of the 1997 general election made what is in any event a tight publishing schedule almost unmanageable. We are grateful to our contributors for meeting our very demanding deadlines. We are also grateful to David Butler and Nigel Allington for advice at a late stage in the process. Our greatest thanks go, however, to our publisher Steven Kennedy, who on top of his customary efficiency and enthusiasm was critical in keeping the book on schedule when it seemed all too likely to fall behind. 
It is no exaggeration to say that this book would not have been published on time without the hard work put in by Steven and his team at Macmillan. We are more than usually grateful to him.

Comments, suggestions and criticism are always helpful and would be greatly welcomed by us. We are currently planning a Developments in British Politics web site for 1998. When ready, this will be accessible through the Macmillan web site: http://www.macmillan-press.co.uk.

Patrick Dunleavy Andrew Gamble Ian Holliday Gillian Peele 